\title{
Social complexity and inequality in the Late Neolithic of the Central Balkans: reviewing the evidence
}

\author{
Marko Porčić \\ Department of Archaeology, Faculty of Philosophy, University of Belgrade, RS \\ mporcic@f.bg.ac.rs
}

\begin{abstract}
The aim of this paper is to review and critically evaluate relevant archaeological evidence regarding recent claims about the social complexity of Late Neolithic societies in the Central Balkans. Theory suggests that the relevant evidence should be related to population size, economic intensification, ranking, and craft specialisation. It is concluded that, although there are indications that inequalities existed and also demographic potential for organisational complexity, there is no unambiguous evidence that institutionalised inequality in the form of complex polities such as chiefdoms or states ever developed.
\end{abstract}

IZVLEČEK - Namen tega članka je pregled in kritična ocena ključnih arheoloških dokazov za nedavno postavljene trditve o družbeni kompleksnosti pozno-neolitskih družb na področju centralnega Balkana. Teoretske diskusije kažejo, da je te dokaze potrebno iskati v velikosti populacij, povečanju proizvodnje, pojavu razredne družbe in obrtni specializaciji. Sklepamo, da kljub kazalcem obstoja družbene neenakosti in demografskega potenciala za organizacijsko kompleksnost ni nedvoumnih dokazov o tem, da se je $v$ tem obdobju kdaj razvila institucionalizirana neenakost $v$ obliki kompleksnih ureditev, kot so poglavarstva ali države.

KEY WORDS - social complexity; social evolution; Late Neolithic; Central Balkans; Vinča culture

\section{Introduction}

It is commonly maintained that Late Neolithic and Early Copper Age societies in Europe did not evolve into archaic states of the kind found in Mesopotamia and Egypt. Recently, the question of scale and complexity of Late Neolithic communities in the Central Balkans has been re-opened by several hypotheses about the organisational properties of Late Neolithic (LN) societies in this region: 1) Late Neolithic communities were hierarchically organised (Crnobrnja 2011; Crnobrnja et al. 2009; Müller 2012) 2) Late Neolithic settlements had urban layouts, with houses organised in regular rows (Crnobrnja 2011; Crnobrnja et al. 2009; Tasić 2008), and 3) specialised pottery production might have been present (Vuković 2011).

These hypotheses generally imply that $\mathrm{LN}$ societies were more complex than previously thought and closer in character to the pre-state or even early state societies of the Near East. In previous studies of the social evolution of LN societies in the Central Balkans a trend of social and economic intensification has been detected (Bankoff, Greenfield 1984; Chapman 1981; 1990; Kaiser, Voytek 1983; Tringham 1992; Tringham, Krstić 1990), but no one has claimed that LN communities were anything more than relatively egalitarian kinship-based agricultural societies living in villages. From this perspective, the recent claims might indeed imply a different picture of the Late Neolithic societies in the Central Balkans and take us back to the problem of socio-cultural evolution in the European Neolithic.

In order to investigate this topic in more detail, the primary aims of this paper are: 1) to establish the relevant conceptual framework and relevant dimensions, based on anthropological and archaeological theories of social complexity; 2) to evaluate LN so- 
cieties in the Central Balkans on each relevant dimension. With this approach, we should be able to study the issues of socio-cultural evolution more systematically and understand social structure and social change in the LN of the Central Balkans.

Understanding the social development of LN societies in Balkans is not merely a matter of 'local' interest. The problem of diverging social trajectories in Europe and the Near East is not a new problem; it goes back to the roots of European social archaeology and to the great architect of European prehistory, Gordon Childe (Sherratt 1989). Childe was interested in explaining the reasons for this divergence, both empirically and theoretically, by exploring the social development of European and Near Eastern societies (Chapman 2009; Childe 1958), and formulating the general mechanisms and archaeological indicators of social evolution towards complex forms of societies such as early states (Childe 1950; Smith 2009). The issue of evolution towards complexity has been further elaborated within anthropology and archaeology (e.g., Blanton et al. 1996; Carneiro 1970; 1986; 2000; Chapman 2003; Feinman, Marcus 1998; Fried 1967; Johnson, Earle 2000; Kosse 1990; 1994; Marcus 2008; Murdock, Provost 1973; Peregrine et al. 2004; Price, Feinman 1995b; Price, Feinman 2010a; Service 1971; 1975; Yoffee 2005). Therefore, the investigation of this problem in the central Balkans has significant theoretical implications for the comparative investigation of the principles and mechanisms of the social evolution of Neolithic societies in general.

\section{Social complexity - conceptual issues}

The concept of complexity has a long history in anthropological thought. The social-evolutionary theory of the $19^{\text {th }}$ century was based on the assumption that cultures changed from simple to complex, with the most complex end of this dimension being equated with Western Civilization (Spencer 1997; Trigger 1998). Lewis Morgan's (1877) developmental sequence of savagery, barbarism and civilization is a classic example of how complexity was conceptualised in the 19th century. In this context, cultural complexity was equated with progress; it was a value-laden, ethnocentric concept.

Neo-evolutionary theory equates an increase in complexity with general evolution as defined by Marshall D. Sahlins and Elman R. Service (1960). The general evolution is seen as a sequence of major evolutionary stages: bands, tribes, chiefdoms and states. In the neo-evolutionary scheme, increase in complexity is mainly seen as an increase in social scale and the degree of hierarchy in society.

Attempts have been made to measure complexity by constructing instruments such as socio-cultural complexity scales. Raoul Naroll developed an index of social development, a measure of social evolution and urbanisation, based on an index theory (Naroll 1956). His approach was to use specific indicators which have "low correlations with each other, but high correlations with the phenomenon being measured" (Naroll 1956.691). He used two indicators of social evolution (craft specialisation and organisational ramification) and one indicator of urbanisation (settlement size) to construct a social development index.

Robert Carneiro conceptualised complexity as a Guttman scale - an additive scale of cultural traits which could be present or absent (Carneiro 1962). Traits were ranked according to their inclusiveness with respect to other traits. A trait which implied the presence (statistically) of several others was ranked higher. If culture A possessed more traits than culture $\mathrm{B}$, it was considered more complex than $\mathrm{B}$. In this way, cultures could be ranked according to complexity. Although Carneiro was criticised for being selective in his choice of cultural traits (Chick 1997), the general validity of his approach was indirectly demonstrated on a diachronic sample which showed that cultural complexity measured as a Guttman scale does increase through time as expected (Peregrine et al. 2004).

Perhaps the most famous scale of cultural complexity was devised by George P. Murdock. Murdock basically followed Naroll's approach and defined complexity as a composite score of several correlated dimensions: Writing and records, Fixity of residence, Agriculture, Urbanisation, Technological specialisation, Land transport, Money, Density of population, Level of political integration, and Social stratification (Murdock, Provost 1973).

Garry Chick (1997) criticised all these approaches on three grounds: the main problem was that none offered a rigorous definition of the complexity construct - what it is that this construct is supposed to measure. In Murdock's defence, Trevor Denton (2004) replied that the cultural complexity scale was never intended to measure a single construct, but to develop a set of criteria to distinguish between stages of development. 
The second problem with the complexity scale, noted by both Chick and Denton, was that there was no specified ontology which specified a relationship between other constructs that "cause and are caused by cultural complexity" (Denton 2004.5). In other words, there was no theory of the causal path and mechanism that linked the indicators and constructs of cultural complexity.

The third criticism was based on the empirical results of the Principal Components Analysis (PCA) of data from the Standard Cross-Cultural Sample (SCSS) (Murdock, White 1969), with Murdock's complexity items as input variables (Chick 1997). Namely, Chick performed a PCA analysis with Varimax rotation on SCSS data and extracted two factors (Chick 1997. 294). He interpreted this result as evidence that the items chosen by Murdock do not reflect a single construct, but two independent constructs. Denton accepted the results, but maintained that this was an expected outcome if items were conceived as individual interrelated constructs rather than indicators of a single construct (Denton 2004). Denton is right in claiming that PCA results can be interpreted in many ways, but it should be noted that the component loadings shown in Chick's paper (Chick 1997. Tab. 2) do not pertain to the original principal components, but to rotated principal components. It is also puzzling that Chick presented the proportion of variance accounted for by the first two unrotated components and then went on to interpret the rotated solution. What is more, original unrotated component loadings were never shown in Chick's paper. For this reason, I performed a PCA without rotation on the same SCCS data. Percentages of variance accounted for by the first two unrotated principal components are identical to those reported by Chick (Tab. 1). However, a different picture from that

\begin{tabular}{|lccc|}
\hline $\begin{array}{l}\text { Principal } \\
\text { Component }\end{array}$ & Eigenvalue & $\begin{array}{c}\% \text { of } \\
\text { Variance }\end{array}$ & $\begin{array}{c}\text { Cumulative } \\
\%\end{array}$ \\
\hline 1 & 5.282 & 52.817 & 52.817 \\
2 & 1.452 & 14.517 & 67.334 \\
3 & 0.683 & 6.827 & 74.161 \\
4 & 0.607 & 6.072 & 80.232 \\
5 & 0.538 & 5.377 & 85.609 \\
6 & 0.425 & 4.248 & 89.858 \\
7 & 0.311 & 3.106 & 92.964 \\
8 & 0.301 & 3.008 & 95.972 \\
9 & 0.262 & 2.620 & 98.592 \\
10 & 0.141 & 1.408 & 100.000 \\
\hline
\end{tabular}

Tab. 1. PCA of the SCCS data; eigenvalues and explained variance. presented by Chick emerges if one looks at the unrotated loading matrix (Tab. 2). It is apparent that all items load positively with relatively high values on the first component, which accounts for the proportion of variance being four times greater than the second. This seems to be consistent with a single construct interpretation, especially given the relatively high Cronbach's alpha value of 0.898 . So which interpretation is correct, the one-dimensional or two-dimensional?

The results of the PCA without rotation and reliability analysis based on Cronbach's alpha are consistent with the one-dimensional interpretation of cultural complexity as a single construct, but the results of the PCA with rotation are consistent with the two-dimensional interpretation. It should be noted that the application of the rotation algorithm will always result in some solution with more balanced amounts of variance accounted for by rotated factors. From this perspective, it can be claimed that Chick is incorrect in claiming that Murdock's items do not reflect a one-dimensional construct. This problem is analogous to the problem of interpreting the intelligence (IQ) construct: is there a single construct of general intelligence or are there several kinds of intelligence (for an excellent popular account of this problem, see Gould 1996). Murdock's complexity scale does measure something, and does so reliably, but the real issue is whether what it measures has a meaningful theoretical interpretation. In this paper, I will align with Denton's (2004) position that complexity is not a single construct, but a set of several constructs measured by Murdock's items. We can certainly use a single scale as a summary for all other items for some purposes (e.g., demonstrating the reality of an increase in complexity through time, or ranking societies according to their scale), but for

\begin{tabular}{|lcc|}
\hline & \multicolumn{2}{c|}{ Component } \\
& $\mathbf{1}$ & $\mathbf{2}$ \\
\hline Political integration & 0.808 & 0.123 \\
Social stratification & 0.796 & 0.209 \\
Density of population & 0.777 & -0.395 \\
Technological specialisation & 0.744 & 0.104 \\
Agriculture & 0.743 & -0.462 \\
Writing and records & 0.713 & 0.481 \\
Urbanisation & 0.704 & -0.074 \\
Money & 0.693 & 0.113 \\
Fixity of residence & 0.686 & -0.613 \\
Land transport & 0.576 & 0.622 \\
\hline
\end{tabular}

Tab. 2. PCA of the SCCS data; loading matrix for the first two components. 
the purposes of an archaeological investigation of social structure and social change, it is more useful to think of complexity as a multidimensional concept and to evaluate the relevant dimensions independently.

This is essentially in accordance with what archaeologists interested in studying social evolution have suggested - the study of past societies on a set of relevant dimensions concurrently (Drennan et al. 2010; Feinman, Neitzel 1984). This kind of approach is best summarised by Robert D. Drennan and colleagues (Drennan et al. 2010.72):

"We see no way to avoid recognizing and dealing simultaneously with many dimensions of variability, even though it is conceptually much more difficult than reducing complexity to a few dichotomies or typologies. One way to integrate the information encapsulated in numerous scales of variability is to think in terms of the correlations between dimensions. If high values on some dimensions correspond to consistently high (or low) values on others, these dimensions form 'packages', and knowing that such packages exist gives us patterns to try to make sense of by building theoretical constructs to account for them. To the extent that existing theory implies the existence of such packages, they can be sought in the archaeological evidence as a means to evaluate the theoretical models. The former (bottom-up) way of working by no means contradicts the latter (topdown) approach. They are complementary. Both bring our knowledge of what happened in prehistory together with the theoretical notions that help us understand how it came to happen that way; they come together in the act of empirical evaluation of theoretical models."

Starting from this framework, the next logical step is to define the relevant dimensions. If the aim is to explore the degree of organisational complexity of LN societies, it makes sense to use dimensions, which correlate with organisational complexity and can be detected archaeologically. A set of 5 dimensions will be considered in this study: demography, social inequality, economic intensification, craft specialisation, and political strategy (the exclusionary-corporate axis as defined by Blanton et al. 1996).

\section{Archaeological background}

The major archaeological phenomenon of the Late Neolithic in the Central Balkans is the Vinča culture, which extended across the region over an area of around $300 \mathrm{~km}^{2}$ (Fig. 1), encompassing Central Serbia, Kosovo, southern parts of Vojvodina, Transylvania, Oltenia, eastern parts of Bosnia and northern parts of Macedonia (Brukner 2003; Chapman 1981; Garašanin 1973; 1979; 1982). In calendar years, Vinča culture appears at 5400/5300 BC and continued until 4650/4600 BC (Borić 2009). In general, Vinča settlements subsisted on a mixed economy typical of the temperate European climate (see Barker 1985; Bogaard 2004): cultivation based on cereals (Borojević 2006; Bottema, Ottaway 1982; van Zeist 2002) and animal husbandry dominated by domestic animals such as cattle, pig, sheep and goat, accompanied by wild species such as red deer, roe deer and wild pig (Blažić 2011; Bökönyi 1988; Dimitrijević 2008; Greenfield 1986; Legge 1990; Orton 2008; Russell 1993).

Sites from this large geographical area shared a similar material culture (e.g., wattle and daub houses, characteristic black pottery and clay figurines), al-

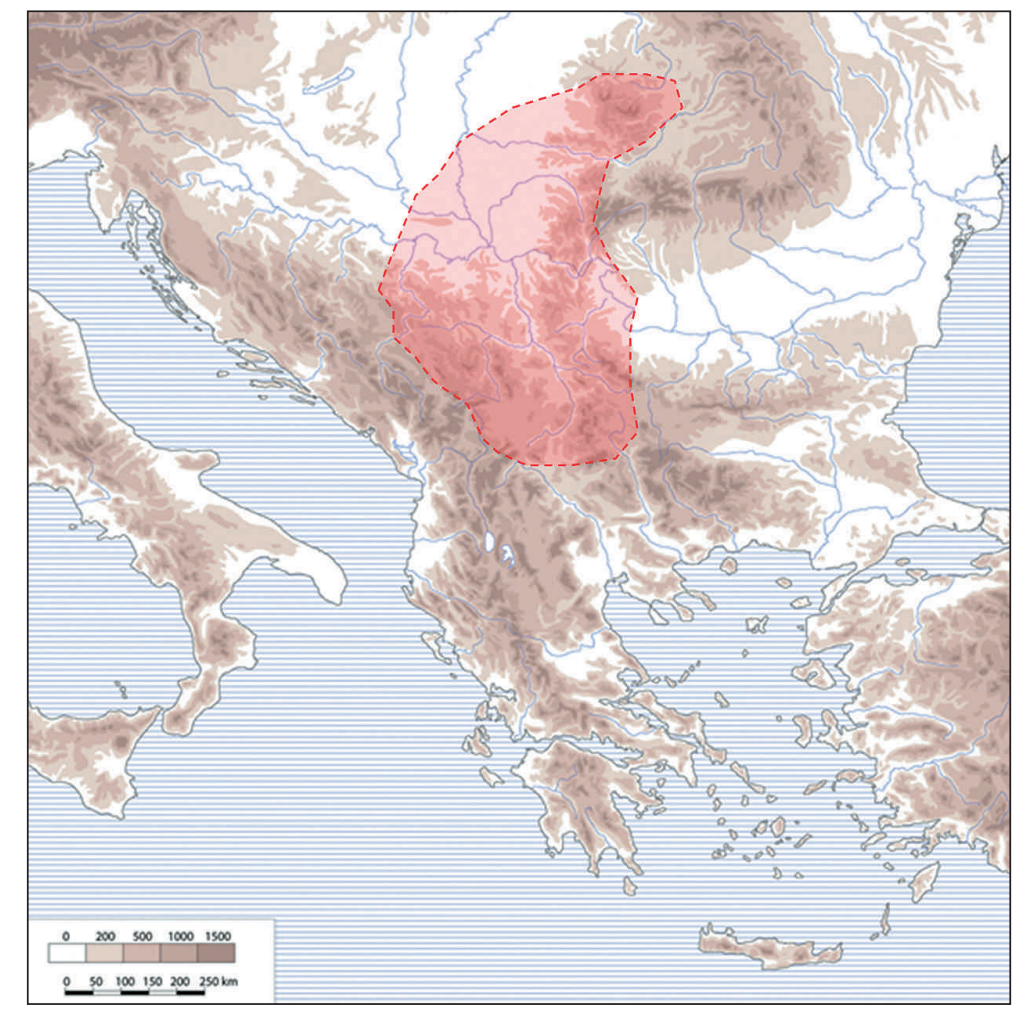

Fig. 1. Approximate distribution of Vinča culture. 
though caution should be taken not to conflate this archaeologically defined entity with anthropological and social entities (political, linguistic or ethnic). Therefore, the term Vinča culture should be understood as a technical label.

\section{Reviewing the evidence}

\section{Demography}

It has been shown in a number of cross-cultural studies that the organisational complexity (often measured by the number of types of political officials, scale of political integration above the local community, or degree of hierarchy and centralisation) of a society is positively correlated with demographic variables such as population size or the population size of the largest community (Carneiro 1986; 2000; Ember 1963; Feinman 2011; Feinman, Neitzel 1984; Johnson 1982).

Gregory Johnson (1982) offered an explanation for the observed empirical pattern: the ability of a group of people to make decisions by consensus or equal participation is limited by group size. Johnson presented the results of small group studies that suggest that the critical group size is six persons. Above this limit, the group is faced with a scalar stress: humans are unable to process information resulting from the interaction of all group members, which leads to inefficiency in the decision-making process. The problem has two potential solutions: sequential hierarchies - the creation of larger basal groups and more levels of decision making (e.g., creating larger households or groups of households which can make decisions by consensus within the group and then send a delegate to negotiate decisions at village level); secondly, simultaneous hierarchies the centralisation of the decision-making process, which results in the rise of managing elites. It should be noted that the number of levels in a sequential hierarchy can be increased only up to a certain point, whereupon the system becomes ineffective because of the long lines of communication between the lowest and highest levels. From this point, simultaneous hierarchy is to be expected.

Efforts have been made to determine the demographic threshold beyond which the organisational change towards complexity (usually toward simultaneous hierarchy) is inevitable. As apparent from Gary M. Feinman's (2011.41.Tab. 3) review, most researchers agree that the critical population size is between 2000 and 3000 people. So in the context of this research, we want to know whether the LN com- munities of the Central Balkans ever reached or crossed this threshold. This is a very conservative test, however, because if the settlement population crossed the threshold, we can be almost certain that hierarchy must have been present. If not, then we have only the absence of evidence, not the evidence of absence, since a community might have consisted of more than a single settlement at the regional level.

To answer this question, population size estimates were made for several LN sites in the Central Balkans with relatively good settlement data. Three estimates are used:

(1) A maximum population size estimate, based on the assumption that an entire area of the settlement was in contemporaneous use. This is obviously a problematic assumption in most cases (Porčić 2011). The estimate is derived by multiplying the (estimated) total number of houses by the estimated average household size. The total number of houses is estimated by the simple proportional extrapolation of the number of excavated or surveyed houses to the unexcavated area. For example, if $50 \%$ of a site area was detected by magnetometer and 40 houses were detected, the estimated total number of houses for the entire site is 80 . The average household size is estimated by dividing the average house floor area by the conversion constant of $7 \mathrm{~m}^{2} /$ person (Porčić 2012a).

(2) An average population size estimate based on the premise that population size was more or less constant during a settlement's history and that only parts of the settlement were used simultaneously. This estimate is calculated by solving Schiffer's (1976; 1987) discard equation, which describes the accumulation of houses in the archaeological record for the systemic number of houses, assuming that the average use-life of houses was 40 years. This estimate was calculated only for sites where the duration of the settlement is known from ${ }^{14} \mathrm{C}$ dates.

(3) Final population size estimates based on the logistic model of population growth (Porčić 2011).

The results are shown in Table 3. Population size estimates suggest that the scalar stress threshold was unambiguously crossed only in the case of Divostin and Stubline and only if the least realistic estimation procedure (which assumes that all houses are contemporaneous) is used. It should also be noted that the projection for Divostin is based on 1.17\% of the total site area, which makes it highly unreli- 
able. Therefore, there is no firm evidence that settlement communities crossed the scalar stress threshold unless the majority of houses at Divostin and Stubline were in contemporary use.

\section{Social inequality - vertical status differentia- tion}

The importance of determining the presence, degree and type of social inequality in a prehistoric society for the study of its social structure and evolution cannot be underestimated. This is best expressed by Douglas T. Price and Gary M. Feinman (2010b.2):

"Social inequality, the organizing principle of hierarchical structure in human society, is manifested in unequal access to goods, information, decision making, and power. Status is the determinant of social position, and status differentiation is the foundation of inequality. A variety of human conditions are used in ordering social hierarchies and in determining status and access. These include age, gender, birth order, class, race, and a number of others. Social inequality is a characteristic of virtually every society on earth today and its history goes back thousands of years. This structure of unequal relations, of status differentiation, is essential to higher orders of social organization and is basic to the operation of more complex societies."

Norman Yoffee (2005.35) also considers inequalities in economic production and exchange as a necessary precondition for the development of complex society forms such as states.

It should be emphasised that inequalities of various kinds are always present in every human society (Flanagan 1989); they may often arise as a result of chance (Mayhew, Levinger 1976; Mayhew, Schollaert 1980; Pauketat 1996). So, as Price and Feinman note (1995a.4), the real question is not whether inequality was present, but what was the degree and

\begin{tabular}{|lcccl|}
\hline \multirow{2}{*}{ Site } & \multicolumn{3}{c}{ Population size estimate } & House data source \\
\cline { 2 - 5 } & Maximum & Average & Final & \\
\hline Divostin IIb & 8200 & 1061 & $868-2684$ & (McPherron, Srejović 1988) \\
Gomolava & 460 & 53 & $70-258$ & (Brukner 1980) \\
Mali Borak & 115 & & & (Marić 2011) \\
Stubline & 4000 & & & (Crnobrnja et al. 2009) \\
Uivar & 420 & 44 & $90-325$ & (Schier 2008) \\
Parta 7b & 823 & 329 & & (Lazarovici et al. 2001) \\
Parta 7c-6 & 1575 & 630 & & (Lazarovici et al. 2001) \\
\hline
\end{tabular}

Tab. 3. Population size estimates. nature of the inequality - e.g., was it institutionalised. This is a traditional issue in social archaeology - to determine the degree of social inequality within a given society. This kind of analysis is usually undertaken with two classes of data - household data and funerary data (Wason 1994). The general aim is to determine the magnitude and pattern of inter-household or inter-individual variation in indicators of social status. In household archaeology, these indicators are house size or house area and the attributes of house inventory. In funerary archaeology, the indicators are the attributes of grave construction and grave goods.

The Gini coefficient is often used in anthropology and economics as a formal measure of inequality in the distribution of a currency (Dorfman 1979; Gastwirth 1972; Smith et al. 2010). The Gini value of 0 indicates that the currency is perfectly equally distributed, while values close to 1 (the highest value that Gini can attain) indicate that the largest share of the currency is held by a minority of the population. Gini coefficients are calculated for two kinds of 'currency': 1) distribution of house floor areas 2) diversity of grave good materials from the only wellrecorded $\mathrm{LN}$ necropolis in the Central Balkans at Gomolava Ib (Borić 1996; Brukner 1980).

The results for household data suggest that differences in house sizes between households were not great (Tab. 4; Fig. 2). However, at Divostin IIb, the correlation between pottery assemblage size 1 and house floor area is relatively high and close to being marginally significant at the 0.05 level $(\mathrm{r}=0.712$, one-tailed $p=0.053$, see Fig. 3). More importantly, copper or malachite artefacts are predominantly found in the group of large houses - a single copper bracelet was found in house 14 (McPherron, Srejović 1988). This pattern may be interpreted as indicative of incipient ranking (for a detailed discussion see Porčić 2012b): larger households have a larger labour force available to intensify production and create surpluses which would enable some households to gain an advantage over others. The association of copper items with large households may indicate their higher status.

The value of the Gini coefficient for the diversity of grave good materials from Gomolava

1 Pot counts for Divostin houses from Porčić (forthcoming); house floor areas from Tripković (2009b). 


\begin{tabular}{|lcl|}
\hline Site & $\begin{array}{c}\text { Gini } \\
\text { coefficient }\end{array}$ & Data source \\
\hline Divostin Ila & 0.2 & McPherron, Srejović 1988 \\
Divostin IIb & 0.15 & McPherron, Srejović 1988 \\
Gomolava Ib & 0.14 & Brukner 1980 \\
Mali Borak & 0.11 & Marić 2011 \\
Parţa 7a & 0.14 & Lazarovici et al. 2001 \\
Parţa 7b & 0.28 & Lazarovici et al. 2001 \\
Parţa 7c & 0.36 & Lazarovici et al. 2001 \\
Stubline & 0.24 & Crnobrnja et al. 2009 \\
Uivar & 0.24 & Schier 2008 \\
\hline
\end{tabular}

Tab. 4. Gini coefficients for house areas from $\mathrm{LN}$ sites in Central Balkans.

cemetery is 0.443 . An important fact should be mentioned about the Gomolava graves: DNA analysis showed that these were all male individuals of the same patrilineage (Stefanovic 2008). The duration of the cemetery was estimated to be approximately 50 years, or two generations (Borić 2009.227). This is important information, because it may suggest that, regardless of the inequality or equality of the distribution of grave goods, only one lineage might have had access to the burial area within the settlement.

\section{Economic intensification}

Economic intensification is also an important aspect and precondition of complexity. One reason for this is ecological - more food and energy is needed to sustain larger populations. The other reason is social the elaboration of society and culture requires in-

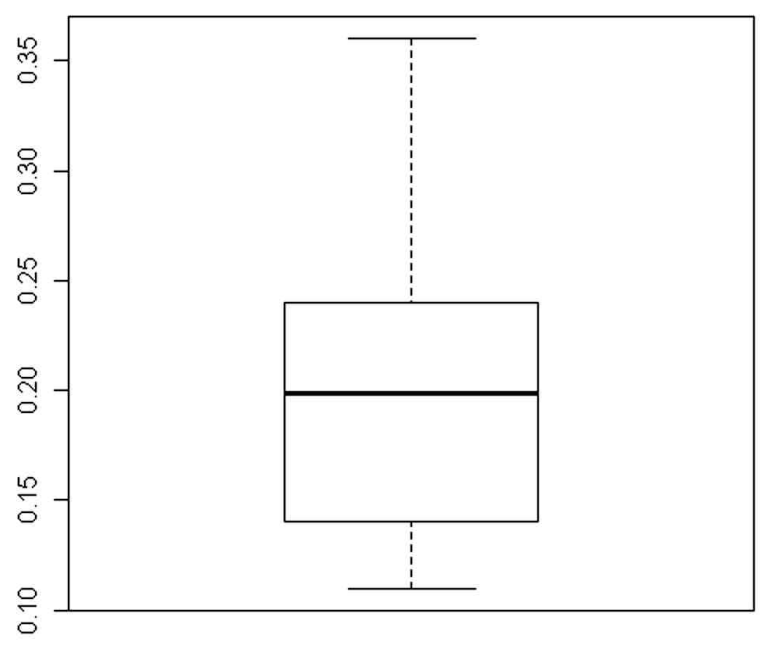

Fig. 2. Boxplot of the Gini coefficients for house floor areas. creases in energy output. For example, processes of vertical and horizontal differentiation in a society produce social positions such as managing officials or craft specialists who do not produce their own food. Their positions need to be supported by the rest of the society, meaning that people who produce food must be producing more to meet the requirements of the entire population. The intensification of production can take many forms, e.g., via technological advance or economies of scale. The consequence is that the domestic mode of production (Sahlins 1972) or peasant economy (Chayanov 1986) gives way to a production system that produces surpluses.

Lightfoot and Feinman's (1982) study provides an excellent example of how these issues can be investigated archeologically. A similar attempt was made to investigate the production of surplus at the LN site at Okolište in Bosnia (Müller 2010). Although Müller's study is based on data from a site of the Butmir culture, which is not in the focus of this study $^{2}$, it is important to report and discuss its results, given that Butmir culture is also a LN culture of the Central Balkans, analogous in many ways to Vinča. Müller (2010) calculated the area of cultivated fields necessary to support each household and also estimated the intensity of agricultural production for each of the seven households identified in the excavated area. The number of quern stones from the household area was used as a proxy measure of the intensity of production. It should be emphasised that the household inventories used by Mül-

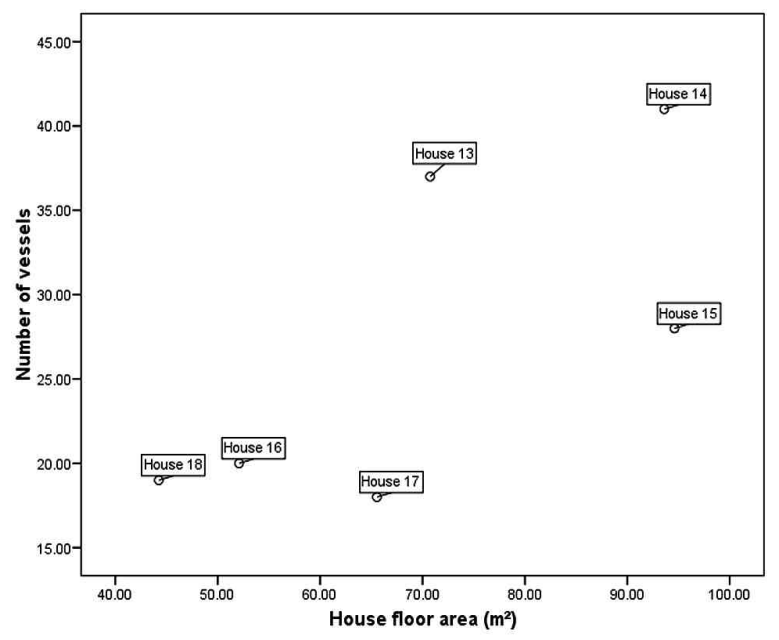

Fig. 3. Plot of house floor area and total number of vessels for Divostin houses.

2 This decision was made for practical reasons only - most of the evidence available to the author comes from the Vinča culture contexts because the Vinča data is from the Republic of Serbia. The Late Neolithic in Bosnia is in many respects similar to the Late Neolithic in Serbia, and a future study should also include sites from this area. 
ler were not closed finds from houses, but items found in layers corresponding to the positions of houses, as well as items found in layers between houses (Müller 2010.54). In theory an increase in the number of consumers in a household (the area of the house and its immediate surrounding was used as a proxy for household size) should be followed by a proportional increase in the intensity of production 3 . The implication is that all households should be on a single line relating the number of consumers to the level of agricultural production (Sahlins 1972.110-111). If intensification had occurred, some households would have under-produced and some would have over-produced, which should be detectable as a deviation from the line - underproducers being under, and over-producers above, the theoretical line. Müller (2010) concluded that his results (reproduced in Fig. 4) could be interpreted as evidence of economic and, therefore, social intensification, with low status households becoming dependent upon high status households.

Another approach is to look for evidence of changes in subsistence in the LN of the Central Balkans, especially changes that indicate intensification. It has been observed that, on the whole, the quantity of cattle bones in zoo-archaeological assemblages from LN sites in the Central Balkans tended to increase (Orton 2010; 2012). This can be interpreted as intensification aimed at meeting the food requirements of a growing population, but it can also be interpreted as an investment in the social arena. Nerissa Russell $(1998 ; 1999)$ suggested that cattle were probably used as a measure of wealth in these societies. The increase in the proportion of cattle may indicate the accumulation of wealth and competition, which resulted in social inequality or perhaps even the horizontal reorganisation of the community, a possible differentiation of pastoral and agricultural sectors, as suggested by David Orton (2010) in a recent paper. It is interesting to note that the presence of transhumance was also hypothesised for LN communities in Bosnia, but it was interpreted as a factor which decreased complexity (Müller-Scheeßel et al. 2010).

\section{Craft specialisation}

Closely related to economic intensification is craft specialisation. In a narrow sense, specialisation or a specialised division of labour is what complexity is all about: differentiating the system and increasing the number of connections between its constituent parts. The presence of craft specialisation was established long ago as a key criterion for diagnosing the presence of a complex social organisation (Childe 1950). While this observation is valid in general, recent studies have shown that this relation is not so simple, and that specialisation itself is also a multidimensional phenomenon (Brumfiel, Earle 1987; Costin, Hagstrum 1995; Feinman 1999; Feinman, Nicholas 2000). For example, a specialist can be independent or attached to a patron; specialised production can be full-time or part-time, small-scale or large-scale. Different social and economic conditions may favour different kinds of specialisation: $e . g$., independent specialisation may develop as a response to resource diversity and population growth, urbanisation, market development and stable demand, while attached specialisation is related to elites and their need to control production (Brumfiel, Earle 1987.5-6), especially of luxury items.

In archaeology, the presence of specialisation is usually diagnosed indirectly by studying the degree of standardisation in technology (Blackman et al. 1993; Costin, Hagstrum 1995; Eerkens 2000; Eerkens, Bettinger 2001; Roux 2003). The most common approach is to study standardisation by looking for the uniformity of raw materials or the variation in met-

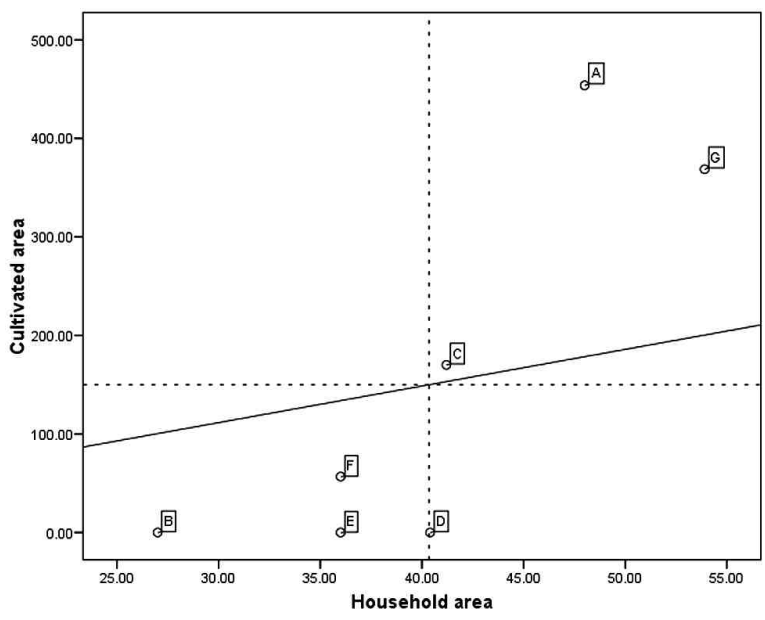

Fig. 4. Expected and reconstructed intensity of agricultural production in LN Okolište (data from Müller 2010.54, Abb.3). The solid line is the theoretical line of expected intensity of production conditional on household size; dotted lines intersect at the centroid of the sample, the $x$ coordinate being the mean household area and y coordinate being the mean expected area of cultivated fields for a given sample of households.

3 Expected intensity of production for each household area was measured by the estimated area of cultivated fields needed to satisfy the needs of a household, while the actual intensity of production was measured as an area of cultivated field calculated as a function of the number of excavated querns within that area. 
ric attributes. The general idea of the latter is that low variation (measured by the coefficient of variation) indicates standardisation, while high variation indicates the absence of standardisation. In some instances, this is confirmed by the results of ethnoarchaeological research (Roux 2003), but it has also been challenged by other ethno-archaeological studies (Arnold 2000; 1991). The link between standardisation and specialisation does hold in general, but is not deterministic. However, an additional problem for analysing standardisation in archaeological contexts is the fact that archaeological assemblages are the result of a cumulative process - deposited pottery is produced by different people at different times - so the variation in metric attributes will always be greater because of the cumulative blurring effect (Blackman et al. 1993).

In a recent study, Jasna Vuković analysed the metric attributes of ceramic bowls from two Late Vinča sites, Vinča (the eponymous site) and Motel Slatina. She found that the coefficients of metric attributes were low, especially the coefficients of variation in the ratios of metric attributes, and concluded that this might suggest that specialisation was present in the LN (Vuković 2011).

Another technological domain where craft specialisation is an important topic is metal production. The LN communities in the Central Balkans were familiar with copper metallurgy (Borić 2009; Jovanović 1971; Radivojević et al. 2010) from the beginning of the $5^{\text {th }}$ millennium BC. When copper metallurgy is in question, there is no doubt that highly specialised knowledge was absolutely necessary for copper production (Ottaway 2001). However, the scarce evidence for copper production at this time cannot be used to estimate the level of specialisation, although approximately 4.7 tons of typologically distinctive massive copper artefacts are known to have circulated in the area (Chernykh 1978; Todorova 1981). Traces of copper smelting activities were detected at sites such as Belovode (Radivojević et al. 2010), Gornja Tuzla (Glumac, Todd 1991) and Selevac (Glumac, Todd 1991; Glumac, Tringham 1990). Multiple exchange networks of raw materials (ores), ingots or finished artefacts within the $5^{\text {th }}$ millennium BC Balkans have been identified through provenance analysis. For instance, metal for typologically identical artefacts from Pločnik (hammer axes) comes from at least four different copper sources from across the Balkans (Pernicka et al. 1997). Similarly, provenance studies show that the metal produced in Belovode was used to make a handful of copper im- plements discovered in several contemporary sites in the region (Radivojević et al. 2010.2785).

\section{Exclusionary-corporate dimension}

One of the key dimensions in the contemporary theory of socio-cultural evolution is the corporate-exclusionary axis, or the distinction between the corporate and network political strategies as presented in dual-processual theory (Blanton, Fargher 2008; Blanton et al. 1996). As defined by Blanton and colleagues (1996), exclusionary strategy is characterised by tendencies of political actors to create elite networks and monopolise flows of goods and information. In other words, they base their power on personal dominance and patron-client relationships. This kind of strategy leads to hierarchical and authoritarian social structures cantered on small ruling elites. In corporate strategy, "power is shared across different groups and sectors in society in such a way as to inhibit the exclusionary strategies" (Blanton et al. 1996.2). Corporate strategies do not preclude the formation of hierarchy or complex social forms; it is merely that the power is differently acquired and deployed. Blanton and colleagues (1990) note that both strategies are present in each society, but one is usually dominant. Therefore, these two strategies do not represent fixed social types; at some point in time, network strategy may be dominant, while at some other point the society can switch to corporate strategy. These two strategies also have material correlates, e.g., in network societies there will be a stronger tendency to signal vertical status through lavish burials, big residences, and prestigious and exotic items (Blanton et al. 1996; Drennan et al. 2010). For this reason, we should expect to find more conspicuous indicators of inequality in network-oriented groups than in corporate groups.

Boban Tripković (2009a.292-297) observed that LN settlements in the northern area of the Vinča culture (sites at Vojvodina and sites close to the Danube) differ from contemporaneous settlements in the south (central and south Serbia). He noted that the northern group is characterised by small houses (implying nuclear family households) and the presence of exotic materials such as spondylus and obsidian (see Dimitrijević, Tripković 2006; Tripković 2004), while large houses (implying extended or multifamily households) and the reliance on local raw materials are typical of the southern group. Tripković interpreted this pattern as a reflection of the underlying social and ideological differences between these two regions - the southern group hav- 
ing relatively closed societies oriented towards corporate and collective values, and the northern group being more competitive and individualising, as evidenced by the creation of networks of exchange for exotic goods. Translated into terms of dual-processual theory, this would mean that there were network-oriented groups in the north, and corporateoriented groups in the south.

\section{Discussion}

In this section, the evidence will be discussed from the perspective of the main research question - where are the LN societies in Central Balkans on various dimensions of social complexity? The central issue turns on the interpretation of the data: if, and to what degree, they indicate complexity and inequality.

Regarding population size and scalar stress, there is evidence that settlements existed with population sizes measuring in the hundreds and with a regular layout of houses reminiscent of urban planning (e.g., Stubline and Vinča). Moreover, there is additional data showing that communal projects such as ditches and palisades were constructed around a great number of LN settlements in the Central Balkans, indicating that people living in the same village constituted a single community (Tripković 2009a). But is this evidence sufficient to conclude that these were actually towns or proto-urban settlements? The argument concerning urban planning is not strong, because the key criteria for distinguishing between villages and towns are socio-economic, not spatial. Gordon Childe noted that no specific elements of urban planning can be proved to be characteristic of early city states (Childe 1950.16). Given the estimated population size of some sites, there was certainly demographic potential for a hierarchical and complex society. However, there is no unambiguous proof that any of them crossed the scalar stress threshold, which would be a sufficient condition to claim for the existence of social hierarchy in Vinča communities.

It has already been mentioned that the Divostin site included several large households. This is also true of the site at Stubline (Porčic 2010.261-268). For both of these sites, the estimated average household size is around 8 persons (Porčić 2010). Tripković (2009b) demonstrated that the large houses and households at Divostin were a result of the household continuity strategy practices of some households. The creation of larger households through a household continuity strategy could have been a way to accumulate labour and intensify production, mo- tivated by the desire to achieve higher status (Porčic 2012b). This interpretation would be in accordance with Crnobrnja's (2011) proposition that LN societies in the Central Balkans were hierarchically structured where individuals were unequal in their status. Johannes Müller's (2010) study of social inequality in Okolište comes closest to demonstrating such a scenario. However, Müller's study, conceptually ingenious as it is, can be criticised on several grounds:

(1) The analysis does not take into account formation processes; it is simply assumed that the spatial layout of querns in the cultural layer directly reflects their primary context of use and deposition. Such an assumption may lead to a conflation of the systemic and archaeological contexts (Schiffer 1976; 1985). This may be a valid assumption in some cases, but given the complexities of the formation processes of LN tells in the Central Balkans (Chapman 2000a; 2000b; Chapman, Gaydarska 2007) it would be necessary to demonstrate empirically that the items found within and around houses represent de facto refuse or primary refuse, or that secondary refuse from a particular house was deposited in the vicinity of that house.

(2) The validity of the number of querns as a correlate of agricultural intensification is problematic. Why should the increase in agricultural output scale linearly with the number of quern stones?

(3) The way that data are organised might have biased the results. Some houses were not completely excavated, so the demonstrated high correlation between household area and number of querns may be a product of this bias. If the querns were distributed more or less uniformly in the cultural layer, then one would expect to find more querns in larger areas. In this scenario, the number of querns would depend only on the size of an excavated area, producing the same pattern of correlation.

Therefore, socio-economic intensification is a good candidate for explaining the appearance of large households, but it is far from being sufficiently corroborated by empirical evidence. Moreover, the motivation for making larger households might have been completely different. Gregory A. Johnson (1982) noted that one way to counter the formation of centralised hierarchies and enable the functioning of a relatively egalitarian decision-making process is to create larger households and thus reduce the number of independent units that need to reach con- 
sensus in the process. Taking into account the fact that large houses are usually associated with large sites such as Divostin and Stubline, where scalar stress was higher than in smaller settlements (Porčic 2010; 2011), the observed patterns may not be interpreted as a trend towards higher inequality, but as an attempt to avoid centralisation and stratification by creating sequential hierarchies. Additionally, data from sites which were extensively surveyed by magnetometer, like Uivar (Schier 2006; 2008) and Stubline (Crnobrnja et al. 2009), show that the Gini coefficients based on the distribution of house floor area are low. After all, it has been shown that the socio-cultural trajectories of societies with large villages can be very different and do not necessarily lead to state formation (Bandy 2004; 2008).

There are also two important observations that might suggest that considerable social inequality existed in Vinča culture societies: the association of copper items with the largest houses and the exclusive access to the settlement cemetery for members of a single patrilineage. Caution must be exercised in order not to over-interpret these observations. Firstly, the association of copper items and large households is present only at Divostin and is based on data drawn from a very small number (6) of excavated houses. Secondly, the meaning and function of copper artefacts in LN societies is not fully understood (see Greenfield 1999; Jovanović 1971; Orton 2008. 268 ); they might have been status markers, as hypothesised for the Gomolava necropolis (Boric 1996).

The fact that individuals interred at the Gomolava cemetery all belonged to a single patrilineage may be an additional argument for demonstrating inequality embodied through exclusive access to the intramural cemetery for members of a single descent group, but an alternative explanation can also be offered: the patrilineage interred at the cemetery was not privileged, but was the only lineage or the most numerous in the settlement. This would mean that the cemetery population is a reflection of the entire male population of the settlement. There seems to be a good match between the average population size estimate of 53 people, and the number of individuals in the cemetery multiplied by 2 to account for the missing females $(28 \cdot 2=56)$. These two values are not directly comparable, because the number of people in the cemetery is a result of a cumulative process, but the average male population size can be estimated from the number of interred individuals using the standard formulat (Acsádi, Nemeskéri 1970.65). The value of this estimate is 20 males, which translates into a total of 40 people when females are taken into account. This is also very close to the average population estimate of 53 people based on the number of houses. However, the hypothesis that the kin group buried in the cemetery was the only lineage in the settlement rests upon the assumption that the population was stationary. Judging by the increase in the number of houses through time in Gomolava, this assumption seems questionable (Porčić 2010.344-345). If the population was growing, then the final population size estimate is more realistic, but the number of interred individuals is too small to assume that it reflected the entire living male population. Of course, it is always possible that there is a more trivial explanation, that individuals from other descent groups were buried in the unexcavated portions of the settlement. But even if the hypothesis that a single descent group or parts thereof had exclusive access to this cemetery seems true, this may still be interpreted as evidence of ranking, not necessarily stratification (sensu Fried 1967).

The inventory of both the largest house at the site at Divostin (McPherron, Srejovic 1988) and one of the Gomolava graves included copper bracelets (Boric 1996; 2009; Brukner 1977; 1980). The social meaning and function of copper items is closely related to the issue of craft specialisation. Which people possessed the technological knowledge to smelt copper? Does their presence alone indicate the existence of elites or a stable market indicative of political integration above the local community? It is a common assumption that the presence of metallurgy implies hierarchy and elites interested in the control of metal production and distribution, but this view has recently been challenged (Bartelheim 2009; Kienlin, Stöllner 2009). There are models, which do not require the existence of elite patrons who commission specialised metallurgists. For example, Stephen Shennan presented a hypothesis, based on $R i$ cardo's 'law of comparative advantage,' that entire communities could have specialised in producing metals and exchanged the products for farming produce with farming communities (Shennan 1999). In this scenario, elites are not required to sponsor metallurgy; what is needed for such a specialised system is a constant demand for metal products.

\footnotetext{
4 The expectation of life at birth was assumed to be 26.9 years, which is an empirically derived estimate for the Neolithic (Acsádi, Nemeskéri 1970).
} 
Things are also complicated by the potential specialisation of pottery production. Vuković (2011) has shown that the variation of several metric attributes is within the range expected for specialisation when cumulative blurring is taken into account. Vuković calculated the coefficients of the variation in ratios of metric attributes, with the result that some of the resulting values were below or close to the Weber fraction (3\%), which reflects the accuracy of human perception (Eerkens 2000). However, the value of $3 \%$ was empirically determined only for one-dimensional variables such as length; it is not known if the same error rate applies to the ability to distinguish between shapes. Whatever the case, even if there were pottery specialists in LN villages, production might still have been at the household level and was not necessarily a full-time specialisation (Vuković 2011).

\section{Conclusion}

The general conclusion of this study is that there is no unambiguous evidence of institutionalised inequality and stratification in LN communities in the Central Balkans, barring fragmentary evidence of social ranking. Although the demographic and technological potential for the evolution of complex and hierarchical societies (e.g., chiefdoms) was present, there is no proof that these developed in the LN of the Central Balkans. Given that LN societies in the northern areas of the Vinča culture were probably network oriented, the eventual development of com- plex chiefdoms and proto-urban societies would be most readily detectable in this region. No such development has thus far been observed in the archaeological record. The current evidence does not allow us to speak of the LN civilisation, towns or supra-regional polities.

It should be emphasised that the available evidence for almost every aspect of $\mathrm{LN}$ societies in the Central Balkans is scarce due to the fact that there have been very few large-scale excavations. The available data barely allows any generalisations. For this reason, scholars interested in this topic should make general claims with great caution, while inferences about the social system should not be based on a single criterion.

$$
\text { ACKNOWLEDGEMENTS }
$$

This research was undertaken as part of project No. 177008 funded by the Ministry of Science and Technological Development of the Republic of Serbia. The paper is based on the talk delivered at the $18^{\text {th }}$ Neolithic Seminar in Ljubljana. I am grateful to Professor Mihael Budja for providing me with the opportunity to participate in the Neolithic Seminar. I would also like to thank the participants of the $18^{\text {th }}$ Neolithic seminar for their useful comments. Special thanks go to Miljana Radivojevic for providing comments and suggestions, especially regarding metallurgy in the Late Neolithic. Of course, the responsibility for errors and omissions is mine alone.

\section{References}

Acsádi G., Nemeskéri J. 1970. History of Human Life Span and Mortality. Akademiai Kiado. Budapest.

Arnold D. E. 2000. Does the Standardization of Ceramic Pastes Really Mean Specialization? Journal of Archaeological Method and Theory 7: 333-375.

Arnold P. J. III 1991. Dimensional Standardization and Production Scale in Mesoamerican Ceramics. Latin American Antiquity 2: 363-370.

Bandy M. 2004. Fissioning, Scalar Stress, and Social Evolution in Early Village Societies. American Anthropologist 106: 322-333.

2008. Global Patterns of Early Village Development. In J.-P. Bocquet-Appel and 0. Bar-Yosef (eds.), The Neoli- thic Demographic Transition and its Consequences. Springer, Berlin: 333-357.

Bankoff A. H., Greenfield H. J. 1984. Decision-making and culture change in Yugoslav Bronze Age. Balcanica 15: 731 .

Barker G. 1985. Prehistoric Farming in Europe. Cambridge University Press. Cambridge.

Bartelheim M. 2009. Elites and Metals in the Central European Early Bronze Age. In T. Kienlin and B. Roberts (eds.), Elites and Metals in the Central European Early Bronze Age. Dr Rudolf Habelt GMBH, Bonn: 34-66.

Blackman M. J., Stein G. J. and Vandiver P. B. 1993. The Standardization Hypothesis and Ceramic Mass Production: 
Technological, Compositional, and Metric Indexes of Craft Specialization at Tell Leilan, Syria. American Antiquity 58: $60-80$.

Blanton R., Fargher L. 2008. Collective Action in the Formation of Pre-Modern States. Springer. New York.

Blanton R. E., Feinman G. M., Kowalewski S. A. and Peregrine P. N. 1996. A Dual-Processual Theory for the Evolution of Mesoamerican Civilization. Current Anthropology 37: 1-14.

Blažić S. 2011. Fauna kasnovinčanskih staništa Crkvine i Belež. Kolubara 5: 239-250.

Bogaard A. 2004. Neolithic Farming in Central Europe. Routledge. London.

Bökönyi S. 1988. The Neolithic fauna of Divostin. In A. McPherron, D. Srejović (eds.), Divostin and the Neolithic of Central Serbia. University of Pittsburgh, Pittsburgh: 419-445.

Borić D. 1996. Social Dimensions of Mortuary Practices. Starinar 47: 67-83.

2009. Absolute Dating of Metallurgical Innovations in the Vinča Culture of the Balkans. In T. Kienlin, B. Roberts (eds.), Metals and Societies: Studies in Honour of Barbara S. Ottaway. Dr Rudolf Habelt GMBH, Bonn: 191-245.

Borojević K. 2006. Terra and Silva in the Pannonian Plain: Opovo agro-gathering in the Late Neolithic. Archaeopress. Oxford.

Bottema S., Ottaway B. S. 1982. Botanical, malacological and archaeological zonation of settlement deposits at Gomolava. Journal of Archaeological Science 9: 221-246.

Brukner B. 1977. Beitrag zur Ferstellung des Beginns der Metallurgie und der Aeneolithisierung. Archaeologia Iugoslavica 18: 9-12.

1980. Naselje vinčanske grupe na Gomolavi (neolitski i ranoeneolitski sloj). Rad vojvođanskih muzeja 26: 555.

2003. Vinčanska kultura u prostoru i vremenu. Rad muzeja Vojvodine 43-45: 7-28.

Brumfiel E. M., Earle T. K. 1987. Specialization, Exchange, and Complex Societies. In E. M. Brumfiel, T. K. Earle (eds.), Specialization, Exchange, and Complex Societies. Cambridge University Press, Cambridge: 1-9.
Carneiro R. L. 1962. Scale Analysis as an Instrument for the Study of Cultural Evolution. Southwestern Journal of Anthropology 18: 149-169.

1970. A Theory of the Origin of the State. Science 169: $733-738$.

1986. On the Relationship between Size of Population and Complexity of Social Organization. Journal of Anthropological Research 42: 355-364.

2000. The Transition from Quantity to Quality: A Neglected Causal Mechanism in Accounting for Social Evolution. Proceedings of the National Academy of Sciences of the United States of America 97: 1292612931.

Chapman J. 1981. The Vinča Culture of South East Europe. BAR. Oxford.

1990. The Neolithic in the Morava-Danube Confluence Area: A Regional Assessment of Settlement Pattern. In R. Tringham, D. Krstić (eds.), Selevac: A Neolithic Village in Yugoslavia. University of California, Los Angeles: 13-43.

2000a. Pit-digging and structured deposition in the Neolithic and Copper Age of Central and Eastern Europe. Proceedings of the Prehistoric Society 61: 61-87.

2000b. Rubbish-dumps' or 'places of deposition'?: Neolithic and Copper Age settlements in Central and Eastern Europe. In A. Ritchie (ed.), Neolithic Orkney in its European context. MacDonald Institute, Cambridge 347-362.

2009. The Danube and Settlement Prehistory - 80 Years On. European Journal of Archaeology 12: 145-156.

Chapman J., Gaydarska B. 2007. Parts and Wholes: Fragmentation in Prehistoric Context. Oxbow Books. Oxford.

Chapman R. 2003. Archaeologies of Complexity. Routledge. London.

Chayanov A. V. 1986. The Theory of Peasant Economy. University of Wisconsin Press. Wisconsin.

Chernykh E. N. 1978. Gornoe delo i Metallurgiya $v$ dreivneishei Bolgarii. Bolgarskoi Akademiii Nauk. Sofia.

Chick G. 1997. Cultural Complexity: The Concept and Its Measurement. Cross-Cultural Research 31: 276-307.

Childe V. G. 1950. The Urban Revolution. The Town Planning Review 21: 3-17. 
1958. The prehistory of European society. Pelican books. Harmondsworth. Middlesex.

Costin C. L., Hagstrum M. B. 1995. Standardization, Labor Investment, Skill, and the Organization of Ceramic Production in Late Prehispanic Highland Peru. American Antiquity 60: 619-639.

Crnobrnja A. N. 2011. Arrangement of Vinča culture figurines: a study of social structure and organisation. In M. Budja (ed.), 18th Neolithic Seminar. Documenta Praehistorica 38: 131-147.

Crnobrnja A. N., Simić Z. and Janković M. 2009. Late Vinča Culture Settlement in Crkvine at Stubline. Starinar 59: 9-25.

Denton T. 2004. Cultural Complexity Revisited. Cross-Cultural Research 38: 3-26.

Dimitrijević V. 2008. Vertebrate Fauna of Vinča - Belo Brdo (Excavation Campaigns 1998-2003). Starinar 56: 245-269.

Dimitrijević V., Tripković B. 2006. Spondylus and Glycymeris bracelets: trade reflections at Neolithic Vinča-Belo Brdo. In M. Budja (ed.), 13th Neolithic Seminar. Documenta Praehistorica 33: 237-252.

Dorfman R. 1979. A Formula for the Gini Coefficient. The Review of Economics and Statistics 61: 146-149.

Drennan R. D., Peterson C. E. and Fox J. R. 2010. Degrees and Kinds of Inequality. In T. D. Price, G. M. Feinman (eds.), Pathways to Power: New Perspectives on the Emergence of Social Inequality. Springer, New York: 45-76.

Eerkens J. W. 2000. Practice Makes Within 5\% of Perfect: Visual Perception, Motor Skills, and Memory in Artifact Variation. Current Anthropology 41: 663-668.

Eerkens J. W., Bettinger R. L. 2001. Techniques for Assessing Standardization in Artifact Assemblages: Can We Scale Material Variability? American Antiquity 66: 493-504.

Ember M. 1963. The Relationship between Economic and Political Development in Nonindustrialized Societies. Ethnology 2: 228-248.

Feinman G. M. 1999. Rethinking Our Assumptions: Economic Specialization at the Household Scale in Ancient Ejutla, Oaxaca, Mexico. In J. M. Skibo, G. M. Feinman (eds.), Pottery and People: A Dynamic Interaction. The University of Utah Press, Salt Lake City: 85-104.

2011. Size, Complexity, and Organizational Variation: A Comparative Approach. Cross-Cultural Research 45: $37-58$.
Feinman G. M., Marcus J. 1998. Archaic States. School of American Research Press. Santa Fe.

Feinman G. M., Neitzel J. 1984. Too Many Types: An Overview of Sedentary Prestate Societies in the Americas. In M. B. Schiffer (ed.), Advances in Archaeological Method and Theory Vol. 7. Academic Press, New York: 39-102.

Feinman G. M., Nicholas L. M. 2000. High-Intensity Household-Scale Production in Ancient Mesoamerica: A Perspective from Ejutla, Oaxaca. In G. M. Feinman, L. Manzanilla (eds.), Cultural Evolution: Contemporary Viewpoints. Kluwer Academic/Plenum Publishers, New York: 119-142.

Flanagan J. G. 1989. Hierarchy in Simple "Egalitarian" Societies. Annual Review of Anthropology 18: 245-266.

Fried M. H. 1967. The Evolution of Political Society: An Essay in Political Anthropology. McGraw-Hill. New York.

Garašanin M. 1973. Praistorija na tlu SR Srbije. Sprska književna zadruga. Beograd.

1979. Centralnobalkanska zona. In A. Benac (ed.), Pra istorija jugoslavenskih zemalja. Svetlost, Sarajevo: 79-212.

1982. The Stone Age in the Central Balkan Area, Cambridge Ancient History, Volume 3, Part 1. Cambridge University Press, Cambridge: 75-135.

Gastwirth J. L. 1972. The Estimation of the Lorenz Curve and Gini Index. The Review of Economics and Statistics 54: 306-316.

Glumac P., Todd J. A. 1991. Early Metallurgy in Southeast Europe: the Evidence for Production. In P. Glumac (ed.), Recent Trends in Archaeometallurgical Research. MASCA Research Papers in Science and Archaeology. University of Pennsylvania, Philadelphia: 8-19.

Glumac P., Tringham R. 1990. The exploitation of copper minerals. In D. Krstić, R. Tringham (eds.), Selevac: A Neolithic Village in Yugoslavia. University of California, Los Angeles: 549-563.

Gould S. J. 1996. The Mismeasure of Man. W. W. Norton \& Company. New York.

Greenfield H. J. 1986. The paleoeconomy of the Central Balkans (Serbia): A zooarchaeological perspective on the Late Neolithic and Bronze Age (4500-1000 B.C.). BAR. Oxford.

1999. The Origins of Metallurgy: Distinguishing Stone from Metal Cut-marks on Bones from Archaeological Sites. Journal of Archaeological Science 26: 797-808. 
Johnson A. W., Earle T. 2000. The Evolution of Human Societies: From Foraging Group to Agrarian State. Stanford University Press. Stanford.

Johnson G. A. 1982. Organizational Structure and Scalar Stress. In C. Renfrew, M. Rowlands and B. Segraves (eds.), Theory and Explanation in Archaeology. Academic Press, New York: 389-421.

Jovanović B. 1971. Metallurgy in the Eneolithic Period in Yugoslavia. Arheološki institut. Beograd.

Kaiser T., Voytek B. 1983. Sedentism and Economic Change in the Balkan Neolithic. Journal of Anthropological Archaeology 2: 323-353.

Kienlin T. L., Stöllner T. 2009. Singen Copper, Alpine Settlement and Early Bronze Age Mining: Is There a Need for Elites and Strongholds? In T. Kienlin, B. Roberts (eds.), Metals and Societies: Studies in Honour of Barbara $S$. Ottaway. Dr Rudolf Habelt GMBH, Bonn: 67-104.

Kosse K. 1990. Group Size and Societal Complexity: Thresholds in the Long-Term Memory. Journal of Anthropological Archaeology 9: 275-303.

1994. The Evolution of Large, Complex Groups: A Hypothesis. Journal of Anthropological Archaeology 13: 35-50.

Lazarovici G., Draşovean F. and Maxim Z. 2001. Parța. Museum Banaticum Temeniense. Timişoara.

Legge A. J. 1990. Animals, economy and environment. In R. Tringham, D. Krstić (eds.), Selevac: a Neolithic village in Yugoslavia. University of California Press, Los Angeles: 215-242.

Lightfoot K. G., Feinman G. M. 1982. Social Differentiation and Leadership Development in Early Pithouse Villages in the Mogollon Region of the American Southwest. American Antiquity 47: 64-86.

Marcus J. 2008. The Archaeological Evidence for Social Evolution. Annual Review of Anthropology 37: 251-266.

Marić M. 2011. Crkvine, Mali Borak - naselje vinčanske kulture. Arhitektura i idealna rekonstrukcija objekata od lepa. Kolubara 5: 69-83.

Mayhew B. H., Levinger R. L. 1976. On the Emergence of Oligarchy in Human Interaction. The American Journal of Sociology 81: 1017-1049.

Mayhew B. H., Schollaert P. T. 1980. Social Morphology of Pareto's Economic Elite. Social Forces 59: 25-43.
McPherron A., Srejović D. 1988. Divostin and the Neolithic of Central Serbia. University of Pittsburgh. Pittsburgh.

Morgan H. L. 1877. Ancient Society. Charles Kerr. Chicago.

Müller-Scheeßel N., Hofmann R., Müller J. and Rassmann K. 2010. The Socio-Political Development of the Late Neolithic Settlement of Okoliste/Bosnia-Hercegowina: Devolution by Transhumance? In K. G. S. H. D. i. Landscapes (ed.), Landscapes and Human Development: The Contribution of European Archaeology. Dr. Rudolf Habelt GmbH, Bonn: 181-191.

Müller J. 2010. Zur Rekonstruktion des Mehrproduktes in neolithischen Haushalten. In I. Matuschik, C. Strahm, B. Eberschweiler, G. Fingerlin, A. Hafner, M. Kinsky, M. Mainberger and G. Schöbel (eds.), Vernetzungen: Aspekte siedlungsarchäologischer Forschung. Lavori Verlag, Freiburg: 51-62.

2012. Tells, Fire, and Copper as Social Technologies. In R. Hofmann, F.-K. Moetz and J. Müller (eds.), Tells: Social and Environmental Space. Verlag Dr. Rudolf Habelt GmbH, Bonn: 47-52.

Murdock G. P., Provost C. 1973. Measurement of cultural complexity. Ethnology 12: 379-392.

Murdock G. P., White D. R. 1969. Standard Cross-Cultural Sample. Ethnology 8: 329-369.

Naroll R. 1956. A Preliminary Index of Social Development. American Anthropologist 58: 687-715.

Orton D. 2008. Beyond Hunting and Herding: Humans, animals, and the political economy of the Vinča period. Unpublished $\mathrm{PhD}$ thesis. University of Cambridge. Cambridge.

2010. Both subject and object: herding, inalienability and sentient property in prehistory. World Archaeo$\log y$ 42: 188-200.

2012. Herding, Settlement, and Chronology in the Balkan Neolithic. European Journal of Archaeology 15: $5-40$.

Ottaway B. S. 2001. Innovation, Production and Specialization in Early Prehistoric Copper Metallurgy. European Journal of Archaeology 4: 87-112.

Pauketat T. R. 1996. The Foundations of Inequality within a Simulated Shan Community. Journal of Anthropological Archaeology 15: 219-236. 
Peregrine P. N., Ember C. R. and Ember M. 2004. Universal Patterns in Cultural Evolution: An Empirical Analysis Using Guttman Scaling. American Anthropologist 106: 145-149.

Pernicka E., Begemann F., Schmitt-Strecker S., Todorova H. and Kuleff I. 1997. Prehistoric copper in Bulgaria. Its composition and provenance. Eurasia Antiqua 3: 41-180.

Porčić M. 2010. Arheologija vinčanskih kuća: teorijskometodološki osnovi proučavanja demografije i društvene strukture. Unpublished $\mathrm{PhD}$ thesis. University of Belgrade. Belgrade.

2011. An exercise in archaeological demography: estimating the population size of Late Neolithic settlements in the Central Balkans. In M. Budja (ed.), 18th Neolithic Seminar. Documenta Praehistorica 38: 323-332.

2012a. Effects of Residential Mobility on the Ratio of Average House Floor Area to Average Household Size: Implications for Demographic Reconstructions in Archaeology. Cross-Cultural Research 46: 72-86.

2012b De facto refuse or structured deposition? House inventories of the Late Neolithic Vinča culture. Starinar 62: 19-43.

Price D. T., Feinman G. M. 1995a. Foundations of Prehistoric Social Inequality. In D. T. Price, G. M. Feinman (eds.), Foundations of Social Inequality. Plenum Press, New York: 3-11.

1995b. Foundations of Social Inequality. Plenum Press. New York.

2010a. Pathways to Power: New Perspectives on the Emergence of Social Inequality. Springer. New York.

2010b. Social Inequality and the Evolution of Human Social Organization. In T. D. Price, G. M. Feinman (eds.), Pathways to Power: New Perspectives on the Emergence of Social Inequality. Springer, New York: 1-14.

Radivojević M., Rehren T., Pernicka E., Šljivar D., Brauns M., and Borić D. 2010. On the origins of extractive metallurgy: new evidence from Europe. Journal of Archaeological Science 37: 2775-2787.

Roux V. 2003. Ceramic Standardization and Intensity of Production: Quantifying Degrees of Specialization. American Antiquity 68: 768-782.

Russell N. 1993. Hunting, Herding and Feasting: Human Use of Animals in Neolithic Southeast Europe. University of California. Berkeley.
1998. Cattle as wealth in Neolithic Europe: Where's the beef? In D. W. Bailey (ed.), The Archaeology of Value: Essays on Prestige and the Processes of Valuation. BAR IS 730. Archaeopress, Oxford: 42-54.

1999. Symbolic dimensions of animals and meat at Opovo, Yugoslavia. In J. Robb (ed.), Material Symbols: Culture and Economy in Prehistory. Center for Archaeological Investigations, Southern Illinois University at Carbondale, Carbondale: 153-172.

Sahlins M. D. 1972. Stone Age Economics. Aldine Publishing Company. Chicago.

Sahlins M. D., Service E. R. 1960. Evolution and Culture. The University of Michigan Press. Ann Arbor.

Schier W. 2006. Neolithic House Building and Ritual in the Late Vinča Tell Site of Uivar, Romania. In N. Tasić, C. Grozdanov (eds.), Homage to Milutin Garašanin. Serbian Academy of Sciences and Arts, Macedonian Academy of Sciences and Arts, Belgrade: 325-339.

2008. Uivar: a late Neolithic-early Eneolithic fortified tell site in western Romania. In D. Bailey, A. Whittle and D. Hoffmann (eds.), Living Well Together? Settlement and Materiality in the Neolithic of South-East and Central Europe. Oxbow, Oxford: 54-67.

Schiffer M. B. 1976. Behavioral Archeology. Academic Press. New York.

1985. Is There a "Pompeii Premise" in Archaeology? Journal of Anthropological Research 41: 18-41.

1987. Formation Processes of the Archaeological Record. University of Utah Press. Salt Lake City.

Service E. R. 1971. Primitive Social Organisation. Random House. New York.

1975. Origins of the State and Civilization. Norton. New York.

Shennan S. 1999. Cost, benefit and value in the organization of early European copper production. Antiquity 73 : 352-363.

Sherratt A. 1989. V. Gordon Childe: Archaeology and Intellectual History. Past \& Present: 151-185.

Smith E. A., Mulder M. B., Bowles S., Gurven M., Hertz T. and Shenk M. K. 2010. Production Systems, Inheritance, and Inequality in Premodern Societies. Current Anthropology 51: 85-94. 
Smith M. E. 2009. V. Gordon Childe and the Urban Revolution: a historical perspective on a revolution in urban studies. Town Planning Review 80: 3-29.

Spencer C. 1997. Evolutionary approaches in archaeology. Journal of Archaeological Research 5: 209-264.

Stefanović S. 2008. Late Neolithic Boys at the Gomolava Cemetery (Serbia). In K. Bacvarov (ed.), Babies Reborn: Infant/Child Burials in Pre- and Protohistory. Archaeopress, Oxford: 95-99.

Tasić N. 2008. Vinča - metropola kasnog neolita. In D. Nikolić (ed.), Vinča - praistorijska metropola. Filozofski fakultet u Beogradu, Beograd: 15-33.

Todorova H. 1981. Die kupferzeitlichen Äxte und Beile in Bulgarien. Prähistorische Bronzenfunde 9. C. H. Beck. München.

Trigger B. G. 1998. Sociocultural Evolution: Calculation and Contingency. Blackwell. Oxford.

Tringham R. 1992. Life after Selevac: why and how a Neolithic settlement is abandoned. Balcanica 23: 133-145.

Tringham R., Krstić D. 1990. Conclusion: Selevac in the Wider Context of European Prehistory. In R. Tringham, D.
Krstić (eds.), Selevac: A Neolithic Village in Yugoslavia. University of California Los Angeles: 567-616.

Tripković B. 2004. Ležišta opsidijana na centralnom Balkanu? Test kroz arheološke podatke. Starinar 53-54: 163-179.

2009a. Domaćinstvo i zajednica u kasnom neolitu Zapadnog Balkana. Unpublished PhD thesis. University of Belgrade. Belgrade.

2009b. House(hold) continuities in the Central Balkans, 5300-4600 BC. Opuscula Archaeologica 33: 7-28.

Van Zeist W. 2002. Plant husbandry of tell Gomolava, Vojvodina, Yugoslavia. Palaeohistoria 43/44: 87-115.

Vuković J. 2011. Late Neolithic Pottery Specialization. Starinar 61: 81-100

Wason P. K. 1994. The archaeology of rank. Cambridge University Press. Cambridge.

Yoffee N. 2005. Myths of the Archaic State: Evolution of the Earliest Cities, States and Civilizations. Cambridge University Press. Cambridge. 